\title{
The United States and the Articles of Confederation: Drifting Toward Anarchy or Inching Toward Commonwealth?*
}

On June 7, 1776, Richard Henry Lee proposed to the Second Continental Congress " $[t]$ hat these United Colonies are, and of right ought to be, free and independent States," and "[t]hat a plan of confederation be prepared and transmitted to the respective Colonies for their consideration and approbation." 1 Lee's resolution reflected the linkage between independence and confederation in the public mind. ${ }^{2}$ The result was the Articles of Confederation, drafted in 1776-1777 and finally ratified on March 1,1781 , which remained in effect until 1789 and represented the first American experiment with a written national charter. ${ }^{3}$

The conventional view of this period is that it was dominated by deep factional conflict concerning the amount of power that should be vested in the national government. ${ }^{4}$ The text of the Articles, according to this view, represented a victory for the group favoring minimal national authority, ${ }^{5}$ and as a result the Articles government

- The author acknowledges with gratitude the assistance of Professor William E. Nelson of the Yalc Law School in providing critical guidance and granting permission to make use of unpublished research materials.

1. 5 Journals of the Costinental Cosckess 425 (W. Ford cd. 1906) [hercinafter cited without cross-reference as Joursiss].

2. See New Jersey in the American Revolution, 1763-1783: $\Lambda$ Documest.iry History 402 (L. Gerlach ed. 1975) (issues of independence and confecleration were inseparable) [hereinafter cited as Documestary Histoky]; cf. Jensen, The Arlicles of Confederation, in Fundamental TestameNTs of the AMericax Revolution 62 (Library of Congress Symposium on the American Revolution 1973) (politicians who opposed confecleration did so because they saw it as step toward independence) [hereinafter cited as Jensen, TestAMENTS].

3. Other plans of confederation had been proposed during the colonial period. Sce, e.g., 6 The IVRitings of Benjamin Franki.ls 420-25 (A. Sinjth cd. 1906); 2 History of the Celebrition of til: ONe Huxdredth ANeivrksaky of thi: Promligation of tile, Constitution of the Uxitro States 439 app. (H. Carson cd. 1889); J. Scott, The Unitid States of America: A Stuvy in Internation.lL Okg.inizition 471 app. (1920).

4. See, e.g., H. Hexderson, P.trTy Polmics in the Continintul Congkrss (1074); J. Davis, Sections, Factions, and Political Centralism in the Confederation Period: 1774-1787, at 381.89 (1972) (unpublished doctoral dissertation for Lniscrsity of Wisconsin). Sec generally M. JeNSEN, THe NLw Nation (1950) [bereinafter cited as M. JWoss, Nation].

Professor Jensen is the leading authority on the drafting and text of the Articles by virtue of his book M. JLssis, Titc Akrictes of Confrofkition (19.10) fhereinafter cited as M. JLNSEN, AkTiCLes]. This work has been reprinted with new prefaces (1948, 1959, 1970) reflecting the changes in the author's thinking over the years; the text, however, remains unaltered.

5. See M. Jfinsen, Articles, supra note 4, at 11-12. 
was barely functional. ${ }^{6}$ Its inability to handle crises such as Shays' Rebellion stimulated a centralist reaction that led to the drafting of the Constitution in $1787^{7}$ and the establishment of a stronger national government. ${ }^{8}$

This Note disputes the accepted view of the Articles Period and interprets the years 1777-1789 as ones in which the national government gained and exercised increasing powers. The legal and political institutions created during this period were the basis for the Constitution's national federalism, a political structure characterized by state deference to national power in certain major policy areas and the common recognition of a national citizenship given reality by comity among the states. ${ }^{9}$ Examination of the drafting history and actual text of the Articles suggests that the document was the result of a drive toward union, not an obsession with decentralization. In fact, the national government grew in power and institutional strength from 1777 to 1789 , and the theoretical and institutional structures of the government of the early Constitution Period owed a very substantial debt to those of the Articles Period.

\section{Formal Federalism: The Drafting and Text of the Articles}

The leading historian of the Articles of Confederation asserts that their adoption represented a victory for "radicals," who wanted a weak central government, over "conservatives," who favored greater

6. Sec p. 119 \& note 48 infra (citing sources).

7. Sce M. Stskkey, A Litrle Rebellion 242 (1955) (but for Shays' Rebellion, Federal Constitution might not have come to pass); $R$. TAylor, IVestern Massachusetts IN THE Revolution 103-77 (1954); id. at 168 ("[C]ertainly the upheaval in Massachusetts and the fear that disorder would spread intensified the demand for a stronger central government.")

8. The classic expression of this idea remains J. Fiske, The Critical Period of AMERICAN History 1783-1789 (illustrated ed. 1897). See, e.g., id. at 177.78 ("The events of 1786 impressed upon men's minds more forcibly than ever the wretched and disorderly condition of the country, and went far toward calling into existence the needful popular sentiment in favour of an overruling central government.")

9. The national federalism that began to emerge during the Articles Period thus meant that the states had surrendered certain aspects of their sovereignty, and that the national goternment would deal directly with individuals. See note 151 infra. This Note does not suggest that the Constitution's structure of government was created by the Articles or that today's structure of gorernment appeared in 1789. Rather, it seeks to point out the significant ways in which the government of the carly Constitutional Period rested on that of the Articles Period, just as the government of today rests on that of the carly Constitutional Period. Neither the Articles nor the Constitution, by themselves, created strong centralized structures. Both, for instance, contained broad clauses reserving all powers not delegated to the national government to the states. See U.S. Covst. amend. X; Arricles ef Cosfederation art. II, reprinted in 9 Journals at 908 [hereinafter cited as Aktıcles with page citation to 9 Journals]. 
national power for the protection of property rights. ${ }^{10}$ This conventional view is undermined by a critical examination of the drafting process and the textual provisions of the Articles. The members of Congress displayed a consistent willingness to compromise or surrender elements of state sovereignty in recognition of the overriding need for full national authority in certain areas and for interstate cooperation and comity. The resulting Articles clearly express these principles of national authority and national citizenship.

\section{A. Drafting the Articles}

While the dominance of the "radicals" is conventionally said to be shown by their emasculation of "conservative" John Dickinson's first draft and production of a final draft that left few powers to the central government, ${ }^{11}$ the successive drafts of the Articles ${ }^{12}$ do not show such a steady movement from a strong to a weak central government. For instance, between the first and second drafts, alterations in limiting language served to strengthen the supremacy clause, ${ }^{13}$ enhance central authority over the general budget, ${ }^{14}$ and

10. This thesis is developed at length in M. JENSEN, ARticles, supra note 4. For a clear definition of Jensen's use of the terms "radical" and "conservative," see Jensen, The Idea of a National Government During the American Revolution, 58 Political. ScI. Q. 356, $360 \mathrm{n} .7$ (1943). There is a substantial and growing body of literature that casts doubt on the validity of Jensen's dichotomy. See, e.g., Weir, "The Harmony W'e Were Famous For": An Interpretation of Pre-Revolutionary South Carolina Politics, 26 WM. \& MARY Q. 473 (3d ser. 1969) (study inconsistent with Jensen model); Rakore, Book Review, 6 J. INTERdisciplinary Hist. 744, 746 (1976) (reviewing H. Henderson, supra note 4, and discussing flaws with his approach). See generally Greene, Changing Interpretations of Early American Politics, in The Reinterpretation of Early AMEriciN HISTORY 151 (R. Billington ed. 1966).

11. See M. Jensen, ARTicles, supra note 4, at 130 (theory of Dickinson draft was to make Congress supreme authority; final draft was pact among sovereign states that dele. gated certain powers and retained all others).

12. The first draft of the Articles [hereinafter citcd as Articles (draft 1)] was reported to the Continental Congress on July 12, 1776, by the committee that had been appointed under Lee's resolution, see p. 142 supra, to prepare a plan of confederation. 5 JourNals at 546. The manuscript of this first draft is in the handwriting of John Dickinson of Pennsylvania, is believed to have been largely drafted by him, and is commonly known as the "Dickinson draft" of the Articles.

The first draft was revised by the Committee of the Whole, and a second draft [hereinafter cited as ARTICLEs (draft 2)] was ordered printed on August 20, 1776. 5 Journ.ALs at 689. Further congressional debates led to the printing of a third draft [hereinafter cited as ARTICLEs (draft 3)]. The final version of the Articles was essentially the same as the third draft, with "sundry small amendments made in the diction, without altering the sense." 9 Journals at 907.

13. Compare ARTiCles (draft 1) art. XII, 5 Journals at 678 ("Every Colony shall abide by the Determinations of the United States assembled, concerning the Services performed and Losses or Expences incurred by every Colony for the common Defence or gencral Welfare ....") with Articles (draft 2) art. X, 5 Journ.als at 678 ("Every State shall abide by the determinations of the United States in Congress Assembled, on all questions which by this Confederation are submitted to them.")

14. The first draft read: "The United States assembled shall have Authority for the Defence and Welfare of the United Colonies and every of them, to agree upon and fix 
increase national military powers. ${ }^{15}$ Between the second and third drafts of the Articles, further centralizing changes were made, including the addition of an article granting "the free inhabitants of each of these states . . . all the privileges and immunities of free citizens in the several states," 16 requiring that "[f]ull faith and credit shall be given in each of these states to the records . . . of every other state," ${ }^{17}$ and mandating interstate extradition. ${ }^{18}$ At the same time, the framers further strengthened the budget authority, ${ }^{19}$ and added a provision granting congressional immunity. ${ }^{20}$ Although there were also important changes that weakened national authority, ${ }^{21}$ most notably the strengthening of the article recognizing the reserved powers of the states, ${ }^{22}$ there was no overall movement in that direction. ${ }^{23}$

The drafting process reveals that Congress shared the country's desire for confederation. ${ }^{24}$ The members knew that union could only be

the necessary Sums and Expences . . ." ArTicLes (draft 1) art. XVIII, 5 Journals at 683 (emphasis supplied). The second draft deleted the italicized language, and with it the burdensome requirement that each expenditure be demonstrably for the benefit of each state. See ArTicles (draft 2) art. XIV, 5 Journals at 683.

15. Compare ARTICles (draft 1 ) art. XVIII, 5 Journats at 683 (authority to raise naval forces from states and issuc regulations for them) with ARTICLes (draft 2) art. XIV, 5 JourNals at 682, 684 (authority to build and equip navy and direct its operations).

16. Articles (draft 3 ) art. IV, 9 Journals at 908-09. The first draft contained a weaker form of this provision, ARTICLes (draft 1) arts. V'I, VII, 5 Joursals at 676, dropped from draft 2, that required comity among the states in matters of migration and "Trade, Navigation, and Commerce," but in all other cases restricted citizens of other states to the rights they already enjoyed.

17. Articles (draft 3) art. IV, 9 Jocrn.tLs at 909 . The judicial implementation of this clause is discussed at pp. 159.60 infra.

18. ARTiCles (draft 3) art. IV, 9 Journals at 909; see p. $162 \&$ note 138 infra.

19. Congress, which had previously been authorized only "to agrec upon and fix the necessary sums and expences," ARticLes (draft 2) art. XIV, 5 Jotresiss at 683 , was given the new power "to appropriate and apply" the revenue, ARIICLEs (draft 3) art. XIV, 9 Journals at 920.

20. Articles (draft 3) art. v, 9 Joursits at 910; see p. 161 \& note 135 infra.

21. For example, in the first draft the states "unite[d] themselves so as never to be divided by any Act whatever," and entered into a leaguc of fricndship, Articles (draft 1) art. II, 5 Journsis at 674 . In the succeeding draft the nature of the union was recharacterized to retain only the league of friendship, see ArTicLes (chraft 2) art. II, 5 JournaLs at 674 .

22. See M. JeNsen, ARTiclrs, supra note 4, at 175 (change concerned "basic constitutimal issue of the Revolution"); cf. Letter from Thomas Burke to the Governor of North Carolina (April 29, 1777), reprinted in 2 Letters of Mensbers of the Continental CoNGRESS 345-46 (E. Burnett ed. 1923) (author of change notes that it caused little controversy among members) [hereinafter cited as LerTers]. Compare $\Lambda$ rricles (draft 2) art. III, 5 JourNals at 675 wilh ARTICl.es (draft 3) art. II, 9 Jours.lls at 908.

23. See p. 166 infra (. Ippendix summarizing changes made during drafting of Articles).

24. See, e.g., Jefferson, Noles of Debales in the Continental Congress, in 6 Journali at 1102 (Mr. Chase observed that "our importance, our interests, our peace required that we should confederate"); J. Wirni rspons, Speceh in Congress (July 30, 1776), in 9 THE Works OF JoHN W'ItHekspoon, D.D. 135 (Edinburgh 1805) ("The absolute necessity of union . . . is felt and confessed by every one of us, without exception."); Letter from Corn[clius] Harnett to Governor Caswell (Mar. 20, 1778), reprinted in 13 THE State

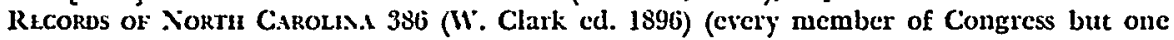


attained if the final version of the Articles proved acceptable to all thirteen state legislatures. The most important objectives of the draftsmen, therefore, were to overcome centrifugal forces ${ }^{25}$ and achieve the greatest possible degree of support for each position taken.

For example, on the volatile issue of the basis of representation in the national legislature, Thomas Jefferson accurately predicted that "the good whigs" would "cede their opinions for the sake of the Union." 20 Although the small states, which favored a one-state, onevote plan, ${ }^{27}$ held a clear majority and could have enacted their wishes at any time, ${ }^{28}$ they engaged in lengthy discussions and numerous attempts at compromise ${ }^{29}$ with the larger states, which favored voting

"seems to wish for a Confederacy") [hereinafter cited as ReconDs]; Letter from Edward Rutledge to Robert R. Livingston (Oct. 2, 1776), reprinled in LETTERs, supra note 22, at 113.

For views of religious leaders, see, e.g., E. Huntington. The Happy Effects of Union and the Fatal Tendency of Divisions 11, 12, 13, 17, 20 (Hartford 1776); R. Ross, A SERMoN IN Which the UNION OF THE Colonies is Considered ANd ReCommended; AND the Bad Conseqlences of Division are Represented 5, 6-7 (New York 1776). For views of private persons, see, e.g., T. PAINe, Common Sense 30, 56, 61, $71-72$ (Philadelphia 1776) (faroring union as soon as possible because it would be more difficult to achieve later); Letter from William Hooper to Robert Morris (Feb. 1, 1777), reprinted in CotLections of THE New-YoRK Historical Society For the Year 1878, at 418 (1879) [hercinafter cited as CoLlections 1878].

In addition to their shared desire for union, the members' agreement on such other matters as the importance of state sorereignty and the need for "virtue" in public officers, both seen as important checks on the corrupting influence of political power on officeholders, smoothed the road to compromise at many points. See, e.g., A. MATHER, The Character of a Well Accomplished Ruler Describ'd (New Haven 1776). See generally The ANTIFEDERALISTs xxv-xxx, xcriii-xcix (C. Kenyon ed. 1966) (discussing sharcd beliefs of political opponents).

25. Concerning the divisions caused by parochialism, see, e.g., H. Henderson, supra note 4 , at $53-54,60,113-20$ (discussing numerous controversies over the appointments of specific generals to the Continental Army); Letter from William Duer to Robert $\mathbf{R}$. Livingston (May 28, 1777), reprinted in LeTress, supra note 22, at 231. Yet these disputes also led to congressional assumption of a conciliating role, exemplified by the resolution: "That a letter be written to General Schuyler, recluesting him to recommend, in the strongest terms, harmony between the officers and troops of the different states; [and] to discountenance and suppress all provincial reflections and ungenerous jealousics of every kind ...." 5 Jour.viss at 591 .

26. Letter from Thomas Jefferson to John Adams (May 16, 1777), reprinted in 2 The Papers of Thom.1s Jcfferson 19 (J. Boyd cd. 1950).

27. On the positions in the representation debate, sec gencrally Adams, Notes of Debates in the Continental Congress, in 6 Journats at 1081; Jefferson, supra note 24, at 1104-06; Letter from William Williams to the Governor of Conncticut (July 5 , 1777), reprinled in LETTERs, supra note 22, at 399-400.

28. The delegates to the first Continental Congress, after a debate similar to that in the second, had decided to give each state one vote at Icast on a temporary basis. The stated ground for this decision was a lack of adcquatc population data. The result was to do what a majority of the delegates wanted without giving offense to the others. See M. JENSEN, AkTicles, supra note 4, at 57-59.

29. For instance, feeling "that the smaller states should be sccued in all questions concerning life or liberty, and the greater oncs in all respecting property," Samucl 
according to population. Eventually, a spirit of compromise prevailed: the delegates achieved virtual unanimity ${ }^{30}$ as the larger states, seeing the need to accommodate the smailer ones, ${ }^{31}$ supported the one-state, one-vote plan.

The process of compromise that marked the drafting debates is clearly visible in the surviving rollcall votes on various other provisions $^{32}$ and in the congressional appeal to the states for ratification of the Articles. ${ }^{33}$ This process was successful in gaining the support of the states. Although nine states formally requested modifications in the Articles, ${ }^{34}$ eleven ratified them within a year of their promulgation, and all thirteen states ultimately did so. ${ }^{35} \mathrm{~A}$ typical response came from the Delaware Council, which felt that the terms of the Articles were "in divers respects unequal and disadvantageous to this state," but ordered its delegates to ratify them because of "the present necessity of acceding to the Confederacy proposed." 36

\section{B. The Text of the Articles}

What is most remarkable about the drafting and ratification of the Articles is that the political community reached broad agreement on a wide variety of provisions that formed the bedrock of a new

Chase of Maryland "proposed that in rotes relating to money, the voice of each colony should be proportioned to the number of it's inhabitants" while each state should have only one vote in all other matters. Jefferson, supra note 24, at 1102. Roger Sherman of Connecticut and Thomas Jefferson both proposed plans under which either the acquiescence or the approval of a majority of both the states and the national population would be required in certain instances. See Adams, supra note 27, at 1081; Letter from Thomas Jefferson to John Adams, supra note 26, at 19.

30 . In the four recorded rollcall votes on representation, the majority position carried by a total of 40 to 5, see 9 Jotrisis at 779-82. The motion to grant each state onc vote carried 10 to $1, i d$.

31. See E. Burnett, The Continental Concress 249 (1941).

32. The records of the sixteen rollcall rotes taken on the Articles are to be found in 9 JouknsLs at 779-82, 801, 803-04, 807-08, 835, 843, 849, 850, 879, 896, 934, 935. Their most salient characteristic is their consistent onc-sidedness; aggregating the results of all these votes, the majority positions carried by a margin of 125-30. Rollcalls normally indicate questions about which there is some disagrement. Large portions of the Articles were approved without dissent by voice rotes. See, e.g., id. at 826, 833-34, 848.

33. See 9 Journals at 932-34 (Articles as proposed are compromise, reflecting "disposition to conciliate" in order to secure plan affording "tolerable prospect of a general ratification," and should be cxamined by legislators in liberal spirit in view of "absolute necessity of uniting").

34. Sce Harmon, The Proposed Amendments to the Articles of Confederation (pts. 1-2), 24 S. ATLINTIC Q. 298, 411 (1925).

35. See 1 Thr. Documcataky Histoky of the Ritification of the Constitution 96137 (M. Jensen ed. 1976) (giving dates and texts of state requests for modifications and state ratifications) [hereinafter cited as RATific.rion].

36. Delaware Council Resolution of January 28, 1779, reprinted in id. at 131. 
national federalism. ${ }^{37}$ The Articles contained significant grants of power and authority to the national government.

The first stone in the federal structure under the Articles was a supremacy clause: "Every State shall abide by the determinations of the United States, in Congress assembled, on all questions which, by this confederation, are submitted to them. And the articles of this confederation shall be inviolably observed by every State. ..."38 This clause was reinforced by a series of prohibitions designed to prevent the states from interfering with the plenary authority granted Congress over military, diplomatic, and commercial affairs. ${ }^{39}$

Furthermore, the Articles granted significant financial powers to the national government. Congress assumed the debts previously incurred for national purposes, ${ }^{ \pm 0}$ and received authority to defray all expenses "that shall be incurred for the common defence or general welfare." 41 To implement this power, the national government was given the exclusive rights to regulate the value of both national and state coinage, "to appropriate and apply the [necessary sums of money] for defraying the public expences," and "to borrow money or emit bills on the credit of the united states." 42 The Articles also created the basis for a national judicial system. ${ }^{43}$ They empowered the gov-

37. See G. Wood, The Creation of the American Republic 1776-1787, at 359 (1969) ("What is truly remarkable about the Confederation is the degree of union that was achieved.") Although recent writers occasionally have taken this vicw, see, e.g., Young, The Articles of Confederation and Perpetual Union, 63 A.B.A.J. 1572 (1977), the Articles are conventionally regarded as having created "a confederation so loose that it had no power," Wright, The Relation of Law in America to Socio-Economic Change, 28 ARK. L. Rev. 440, 450 (1975); see, e.g., 1 J. HARe, American Constitutional Law 16-18 (1889); 1 A. DE Tocqueville, Democracy in America 116-18 (P. Bradley ed. 1945). In setting forth the concept of a national federalism based on deference to national power in certain areas and recognition of a common citizenship, this Note suggests not only that the Confederation government did have power, but also that the existence and exercise of that power had important implications for the future of the country's development.

38. Articles art. XIII, 9 Journals at 925; cf. U.S. Const. art. VI, cl. 2 (supremacy clause). The supremacy clause of the Articles was fully as effective in requiring state judges to follow national policy in those matters committed to national control as is the supremacy clause of the Constitution. See pp. 153-54 \& note 77 infra.

39. See pp. 150-54 infra. The prohibitions on state action are to be found in ARTicles art. VI, 9 JourNals at 911-13.

40. Articles art. XII, 9 Jolrnals at 924; see J. Fiske, supra note 8, at 101 ("[B]y assuming all debts contracted by Congress prior to the adoption of the articles, and solemnly pledging the public faith for their payment, it was implicitly declared that the sovereignty here accorded to Congress was substantially the same as that which it had asserted and exercised ever since the severing of the connection with England.")

41. Articles art. VII, 9 Journats at 913 ; see p. 161 \& note 132 infra.

42. Articles art. IX, 9 Journals at 919-20; see p. 154 infra.

43. For a general discussion of this system, sec Scrgeant, $A$ Brief Sketch of the National Judiciary Powers Exercised in the C'nited States, From the First Settlement of the Colonies to the Time of the Adoption of the Present Federal Constitution, in P. Du Ponceav, a Dissertation on the Nature and Extent of the Jurisdiction of the: Courts of The UNited States 135-58 (Philadelphia 1824). 
ernment to set up "courts for the trial of piracies and felonies committed on the high seas," and also to establish courts with appellate jurisdiction over all prize cases. ${ }^{44}$

In addition to reposing important governmental powers at the national level, the Articles sought to create a system of interstate cooperation and comity. The two most important provisions in this regard were the privileges-and-immunities and the full-faith-and-credit clauses, ${ }^{45}$ provisions that created a "universal intercitizenship" that "gave reality to the nascent and feeble Union." 46 Congress, moreover, was made "the last resort on appeal in all disputes ... between two or more states, concerning boundary, jurisdiction or any other cause whatever." 17

\section{Institutional Federalism: Substantive Powers and the Development of Government Machinery, 1777-1789}

The conventional view is that American political history from the Declaration of Independence to the Constitution was dominated by "the complete inability of the government set up by the Articles of Confederation to function." 43 This view ignores effective exercises of national power that took place during this period and the evolution of institutions extending beyond the text of the Articles. Congress and the state judiciaries often read the Articles broadly and expansively in response to the practical needs of the country. The institutions created by Congress exercised wide powers that furthered national unity, and the states acquiesced.

\section{A. National Powers and Their Expansion}

Even before actual fighting with the British began, the Continental Congresses assumed broad military and administrative powers ${ }^{49}$ with-

44. Articles art. IX, 9 Journals at 916. For a discussion of how Congress used these powers, see pp. 158.59 \& notes $114-16$ infra.

45. See p. 145 supra \& pp. 159.60 infra; The Federalist No. 42 (J. Madison) (privilegesand-immunities clause); Nadelmann, Full Faith and Credit to Judgments and Public Acts, 56 . IICH. L. REv. 33, 33-53 (1957) (full-faith-and-credit clause).

46. J. Fiske, supra note 8 , at 97 .

47. Articles att. IX, 9 Jour.sus at 916; see pp. $155-56$ infra.

48. C. Thach, JR., The Creation of the Presidency, 1775-1789: A Study in Constitution.L HIstoRY 16 (1922); see Miller, An Inquiry into the Relevance of the Intentions of the Founding lathers, With Special Emphasis Lpon the Doctrine of Separation of Pou'crs, 27 ARK. L. REv. 583, 589 (1973); O'Bricn, The Execulive and the Separation Principle at the Constitutional Convention, 55 Mv. Hist. M.MGaziNe 201, 205 (1960).

49. See G. Wood, supra note 37 , at 355 . 
out express legal authority, ${ }^{50}$ and afterwards these developments continued. ${ }^{.1}$ Congress construed its authority broadly within the area of its delegated powers, especially in the war, foreign affairs, and fiscal fields, and continued to assume powers that had not been delegated. According to Madison, a catalogue of congressional actions that were "violations of their chartered authorities" under the Articles "would not a little surprize those who have paid no attention to the subject." ${ }^{52}$ Informed contemporaries ${ }^{\overline{5} 3}$ and the states themselves recognized this developmental process, and most supported it because they agreed upon the desirability of a national confederation and the practical necessity for its expansive assertions of power. $^{54}$

\section{The War Power}

The Revolutionary War was the most important basis for the assertion of broad congressional authority. In prosecuting the war, the national government established practices and institutions that continued long after the fighting had stopped. Congress took those actions it deemed necessary, notwithstanding its lack of formal power, and insisted that its judgment on military matters should be final.": For example, the congressional decision in 1781 to authorize the

50. See Jensen, Testiments, supra note 2, at 61-62; cf. Penhallow vi Doane's Adm'rs, 3 U.S. (3 Dall.) 54, 80-82 (1795) (league cxisted among states prior to Articles and Congress exercised extensive revolutionary powers on its behalf).

51. See 2 1. BRANт, J.Mmes M.ıpiso 129 (1918) (listing wartime actions showing espansive congressional interpretation of gencral welfare).

52. The Federalist No. 42 (J. Madison) 280 (J. Cooke col. 1961).

53. See Letter from Thomas Burke to Gorernor Castell (Mar. 11, 1757), reprinted in 11 Reconds, supra note 24, at 417-18, 421 hereinafter cited as Burke-Ciswell Letter]; Letter from Thomas Paine to Robert Norris (Nov. 20, 1782). refrinted in Councrions 1878, sutra note 24, at 486.

54. See, e.g., Rosenberg. IFilliam Palcrson: Nea Jersey's Nalion-sMaker, 8.5 X.J. Hist. 7, 23-24 (1967) (Paterson and other belicvers in states rights still silw need for stuong confederation); Commentary by "A True Patriot," New Jersey Gatette, April 11, 1781, reprinled in Documantaky Histoky, supra note 2, at 419 (central govemment needs greater authority); Letter from Abraham Baldwin to Charles Thomsm (lel). 14. 1786), reprinled in Collections 1878, supra note 24, at 202-04 (Middle Atlantic and Sonthem states are facorably inclined toward increasing strength of union).

The state of Massachusetts prosecuted in its own name sedition and treasm against the United States, granted agents of the central government immunity from suit on official contracts, and shaped its rules of law to effectuate the national power to isste currency. See Nelson, The American Revolution and the limergence of Meclem Boctrines of Federalism and Conflict of Laws $18 \mathrm{~mm} .67$ \& $68,20 \mathrm{n.75}$ (1969) (unpublished essay on filc with lale Law Journal) (citing cascs); $c f$. Respulslica 1. Swecrs, 1 U.S. (1 Dall.) 41 (Pa. 1779), discussed in note 119 infra (state posecution indsing forging of receipts with intent to defraud United States).

55. See Burke-Caswell Letter, supra note 53, at 421 ("I am often suggesting to Congress that the Civil porier of the States is the best instrument for calling forth their proportion of exertions.. . but they hear with reluctance any thing that looks like the interposition of sucl a power in military affairs . . . .) 
seizure of supplies by the Continental Army has been called "one of the decisive steps of the war," Congress passed was not authorized by any specific provision of the Articles and its terms directly contravened a number of state laws. ${ }^{j i}$ Similarly, the evolution in form and function of the congressional "Board of War and Ordnance" from 1776 to $1787^{\circ 8}$ found its justification in practical rather than legal considerations.

As a general rule, the states cooperated in congressional extension of the war power. Many state courts recognized congressional powers in such military matters as prizes and governance of the army. ${ }^{\tilde{0} 0}$ For instance, the Pennsylvania Supreme Court upheld the power of Congress to "direct the removal of any articles that were necessary to the maintenance of the Continental army, or useful to the enemy," because Congress was "vested with the powers of peace and war." The state legislatures acquiesced in the broad jurisdiction of the military justice system. Although the basis in the Articles for such a power was questionable, ${ }^{61}$ federal military courts exercised jurisdiction not only over military and nonmilitary offenses of soldiers, but also over spying and other illicit conduct by civilians within war zones. ${ }^{62}$ The nationwide use of such authority supplies one example of the way the Continental Army, despite the political disputes it sometimes engendered, ${ }^{63}$ served as an important unifying force. ${ }^{64}$

56. 2 I. BraNr, supra note 51 , at 117 .

57. See id. at 114-17. In 1776, acting on its own authority, Congress had given General Washington the power to impress supplies. It then asked the states to pass laws attthorizing impressments. Not liking the resulting state legislation, which secmed too restrictive, Congress passed the 1781 resolution to orcrride it.

58. See p. 157 infra.

59. See Nelson, supra note 54 , at $19 \& \mathrm{nn} .73-74$.

60. Respublica r. Sparhawk, I U.S. (1 Dall.) 357, 362 (Pa. 1788).

61. Dickinson in preparing his draft of the Articles apparently questioned the propriety of granting to the national government "[t]he power of arresting and trying persons in the Service of the Lnited States, in any Colony, without applying to the Government of such Colony." 5 Jotrals at 550 n.2. The only authority to be found for the actions actually taken is ArTicles art. IX, 9 Jotrsils at 919 (Congress enpowered to make "rules for the government and regulation of the . . . Iand and naval forces").

62. Brief for the Lnited States at 35-42, O'Callahan v. Parker, 395 U.S. 258 (1969) (listing 70 instances prior to 1783 where courts martial assumed jurisdiction of apparently nonmilitary criminal offenses committed by military personnel); Nelson, supra note 54, at $20 \&$ nn.77-80 (citing cases).

63. See, e.g., note 25 supra; 23 JourNaLs at $624-25,629-31$ (friction over nonpayment of Now Jersey troops).

(G4. Sic H. HeNdersos, sufra note 4, at 325 ("The army was a nationalizing force, both because it won the war and because of its unhappy status of being a public creditor:"); H. W.IRv, The DePikTMENT of W'AR 1781-1795, at 41 (1962) (two favorite toasts in the army were "A hoop to the barrel" and "Cement to the Union"). 


\section{Foreign Affairs Powers}

The pre-Constitution Congress exercised considerable power in foreign affairs, and established enduring principles and institutions of national diplomacy. ${ }^{\circ 5}$ For example, representatives of Congress asserted in international negotiations that the United States collectively, and not individually, had succeeded to all the sovereign rights of the British Crown. Although not directly adopted by Congress, ${ }^{\circ 6}$ the idea survived as "a premise of infinite possibilities." ${ }^{\circ}$ It not only framed the national discussion of westward expansion, ${ }^{68}$ but also seems to have served as a source of substantive authority in foreign affairs matters.

Certainly Congress asserted broad authority to make international agreements and enforce them directly against individual Americans. In proclaiming the 1783 treaty of amity and commerce with Sweden, ${ }^{69}$ for example, Congress "enjoined and required" all the citizens and inhabitants of the United States "to govern themselves strictly in all things according to the stipulations" of the treaty. ${ }^{70}$ In 1781 Congress, apparently basing its action on a combination of its war porvers

65. But see, e.g., Olson, The Sonderstrom Incident: A Reflection l'pon Federal-State Relations Under the Articles of Confederation, 55 N.Y. HisT. Soc'Y Q. 109 (1971) (conventional view that national foreign relations power during Articles Period could be and was frustrated by states).

66. See 18 Jourxals at 936 (letter of instructions to John Jay, Minister to France and Spain); Letter from Robert Livingston to Benjamin Franklin (Jan. 7, 1789), reprinled in 5 The Revolutionary Diplomatic Correspondence of the United Stites 89 (F. Wharton ed. 1889) [hereinafter cited as CoRRESPONDENCE]. The inclusion of this claim in a proposed letter to the American peace negotiators triggered a controrersy in Congress in 1783, but the legislators did not push the discussion to any resolution. See Colnections 1878, supra note 24, at $139-45$ (notes of this debate by Secretary of Congress Cliarles Thomson).

67. Corwin, The Progress of Constitutional Theory Between the Declaration of Independence and the Meeting of the Philadelphia Convention, 30 AM. Hist. REv. 511. 528 (1925). The Supreme Court has recently approved this view of the history. In 1975, the Court confirmed the report of a special Master who had declared "that sorcreignty" and dominion passed after independence to the national government in which the powers of external sorereignty were reposed and not to the . . States." Report of Albert B. Maris, Special Master at 63, United States $v$. Maine, 420 U.S. 515 (1975); sec United States v. Curtiss-Wright Export Corp., 299 C'.S. 304, 316 (1936) ("the powers of extcrnal sovereignty passed from the Crown not to the colonies severally, but to the colonies in their collective and corporate capacity as the United States of America").

68. See Collections 1878, supra note 24, at $145-50$ (report by Sccretary Thomson of extensive debate on national sovereignty provoked by petition from residents of "Kentuckey" seeking statehood); Welling, The States'-Rights Conflict Over the Public Lands, 3 Papers Am. Hist. A. $411,416-22$ (1889), reprinted in J. Welling, Addresses, Lectures and Other Papers 208-15 (1904).

69. 8 Stat. 60, T.S. No. 346 (1783).

70. 25 JolikNALs at 614 . Eleven international agreements entered into by the United States during the Articles Period, including treaties of friendship with the Netherlands, Prussia, and Morocco, are to be found at 8 Stat. 6-115. 


\section{Articles of Confederation}

and its power to enter into commercial treaties, ${ }^{71}$ had enacted an ordinance imposing an embargo on all trade with British subjects and warning that the national government would punish individual violators. ${ }^{72}$

In implementing this expansive conception of the national foreign affairs power, Congress was aided by an embryonic federal bureaucracy $^{73}$ and, more importantly from a practical standpoint, by deference from the states and their courts. ${ }^{74}$ Courts in Massachusetts, for example, applied the peace treaty with Great Britain ${ }^{7 \bar{o}}$ in full, where its terms were clear, to override conflicting state policies. ${ }^{76}$ The celebrated New York case of Rutgers $v$. Waddington, ${ }^{77}$ decided in 1784 , probably represented the prevailing view:

The foederal compact hath vested Congress with full and exclusive powers to make peace and war. This treaty [with Great Britain] they have made and ... we are clearly of [the] opinion

71. On the role of the war power in the embargo, see 2.I. BRANT, supra note 51, at 109,111 . For the power to enter into commercial treaties, see ArTiches art. IX, 9 JoURNALs at 915 .

72. See 19 Journals at 315-16 (Americans are "strictly enjoined and required" to observe embargo and "will answer the same at their peril").

73. See pp. 157-58 infra.

74. Several years later, Secretary of State Jefferson noted the acceptance by the states of the superiority of "treaties made by Congress according to the confederation" over "the laws of the States." Letter from Thomas Jefferson to George Hammond (May 29, 1792), reprinted in 1 American State Papers, Foreign Relations 209 (Washington 1833) (quoting state statutes and official documents in support of contention). The strongest congressional assertion of the superiority of treaties to state legislation came in a 1787 circular letter to the states reprinted in 32 JourNals at 177-84.

75. 8 Stat. 80, T.S. No. 104 (1783), reprinted in Documentary Source Book of AMERICAN History 1606-1926, at 204 (IV. MacDonald ed. 1926). Some of the provisions regularly involved in lawsuits were Article IV, providing that creditors on either side should meet with no legal impediments to the recovery of debts previously contracted; Article $V$, stipulating, inter alia, that all persons having any interests in confiscated lands should meet with no legal impediment in the prosecution of their rights; and Article VI, barring future prosecutions or confiscations against any person by reason of the part he may have taken in the war, and requiring the release of all those in custody on such charges.

76. See Nelson, supra note 54 , at $25-29$.

77. Sec 1 The Law Practice of Alexander Hamloton: Documents and CommenTAKY 289-419 (J. Goebel, Jr. cl. 1964) (including transcript of opinion and documentation on case). The case was a statutory trespass action brought to recover damages for defendant's occupation of plaintiff's property during the time New York City was in British hands. Alexanter Hamilton represented the defendant. The Mayor's Court of the City of New York held that part of the action was barred by the provisions of Article VI of the peace treaty with Great Britain, see note 75 supra, the authorizing state statute notwithstanding. See J. Fiske, supra note 8, at 135 (case important for implicit assertion of rights of United States against legislature of single state); Letter from Alexander Hamilton to Thomas Jefferson (Apr. 19, 1792), reprinted in 1 Amertcan State PApers, supra note 74, at 232 (Hamilton's view of case); cf. Respublica v. Gordon, I U.S. (I Dall.) 233 (Pa. 1788) (refusing to sustain suggestion of attainder filed against defendant, because doing so "would contravene an express article in the treaty"). 
that no state in this union can alter or abridge, in a single point, the foederal articles [of confederation] or the treaty. ${ }^{78}$

\section{Financial Powers}

Financial problems plagued the new nation, and, lacking a dependable source of revenue, the Confederation never solved its money troubles. ${ }^{79}$ Nonetheless, on two occasions, twelve of the thirteen states agreed to tariff proposals that would have provided such revenue. ${ }^{80}$ These plans probably would have made the Confederation government fiscally viable, because the mechanisms set up under the Articles for handling the funds that did come in were virtually identical to those existing in the early years under the Constitution..$^{\text {s1 }}$ One such mechanism, although it was of greater symbolic than practical significance, ${ }^{82}$ was the Bank of North America, which Congress incorporated in 1781 in an effort to ease the wartime shortage of capital. ${ }^{83}$ Although this action was assailed as wholly unauthorized by the Articles, its supporters considered it justified by the federal government's "general powers . . . resulting from the union of the whole." 84

\section{Interstate Powers}

The Confederation government also exercised a variety of powers relating to problems that the states could not solve individually. ${ }^{85}$

78. 1 The Law Practice of Alcxander Hamilton, supra note 77, at 413. The court did reserve power to determine "the operation and effects of the treaty" by "a fair and reasonable construction" of it.

79. See generally McLaughlin, The Articles of Confederation, in Essays on THE Making of the Constitution 57-60 (L. Levy ed. 1969).

80. See H. Hendreson, supra note 4, at 325 -38. Interestingly, Virginia initially approved the first revenue-raising plan, which was proposed as an amendment to the Articles, and then effectively killed it by voting to reverse that approval. See id. at 327-28. This would seem to be a precedent for the validity of a state legislature's rescission of its ratification of a constitutional amendment.

81. See generally p. 158 infra.

82. Cf. F. McDonald, E Pluribus Untm: The Formation of the Americin Republic 1776-1790, at 36 (1965) (Bank could help state governments put their finances on an orderly basis, lower prices for imported goods, help manufacturers and farmers, and serve as stabilizing mechanism by controlling money supply).

83. One strong additional motivation for the formation of the Bank is reflected in Robert Morris's desire "to unite the several States more closely together in one general money connexion, and indissolubly to attach many powerful individuals to the cause of our country by the strong principle of self-love and the immediate sense of private interest." Letter from Robert Morris to John Jay (July 13, 1781), reprinted in 4 CoRRESPONDENCE, supra note 66 , at 563 .

84. J. Wilsox, Considerations on the Bank of North America, in 2 ThE Works of JAMES Wilson 829 (R. MicCloskey ed. 1967).

85. Congress delegated an appreciable portion of this job to its President, an officer who sometimes had considerable political influcnce. See generally J. SANDERs, THF. Presidency of the Continental Congress 1774-89: A Stldy in AMerican Institutional History (2d printing, revised 1930); Klingelhofer, The Presidenls of the United States in Congress Assembled (pts. 1-4), 28 Manuscripts 2, 83, 171, 255 (1976). 
One important set of such powers grew out of the formation of a national domain ${ }^{86}$ as states with extensive claims to western lands ceded them to the national government in the interests of interstate harmony. Control over the national domain-an area larger than any existing state-gave Congress an important source of wealth, ${ }^{87}$ political patronage, power, and prestige. Although cession of the western lands was only achieved after considerable political bickering, ${ }^{88}$ this authority served as a powerful unifying force..$^{89}$

Congressional possession of the territory also led to the assertion of broad powers to govern it. Despite the lack of any grant of such a power in the Articles, ${ }^{90}$ Congress passed three major ordinances concerning the territories between 1784 and $1787 . .^{\circ 1}$ In these enactments, Congress strongly asserted its sole authority over these areas, ${ }^{92}$ and set up a detailed plan of territorial governance. ${ }^{93}$ Congress's assertion of its implied powers was thus not confined to fields in which it held delegated authority. In order to extend to the western lands "the fundamental principles of civil and religious liberty" on which the original states had been erected, Congress assumed the power "to fix and establish those principles as the basis of all laws, constitutions, and governments" in those regions. ${ }^{94}$

The Congress was also active in settling disagreements among the states. The Articles set out in considerable detail the procedures for

86. For an cxplanation of the various cessions of state lands by which Congress came into the control of these areas, sce Jensen, The Creation of the National Domain, 178117St, 26 Miss. Vhlley Hist. Rev. 323 (1939-40).

87. See The Federalist No. 38 (J. Madison); J. Davis, supra note 4, at 118, 155, 455 n.139; Letter from John Adams to Mr. Calkoen (Oct. 26, 1780), reprinted in 7 THE WoRks of Johw Adals 298 (C. Adams ed. Boston 1854).

88. See M. Jensen, ARticles, supta note 4, at 198-224.

89. See H. Hendrerson, supra note 4 , at 259 ("the West constituted a lure holding the Confederation together, for only a united confecteration could successfully exploit its resources"); Hutchinson, Unite to Divide; Divide to Unite: The Shaping of American Federalism, 46 Miss. Valley Hist. Rev. 3, 9 (1959) (West became chief link between states because it instilled confidence in payment of national debt, presented foreign issues requiring national response, and caused expansion of congressional authority).

90. See The Federalist No. 38 (J. Madison); J. Fiske, supra note 8, at 221-23; Hutchinson, stupra note 89 , at $10-11$.

91. Ordinance for the Government of Western Territory (Apr. 23, 1784), reprinted in RATIFICATION, supra note 35, at 150-53; Ordinance for the Sale of Western Lands (May 20, 1785), reprinted in id. at 156.63; Ordinance for the Government of the Territory of the United States North-West of the River Ohio (July 13, 1787), reprinted in id. at 168-74 [hereinafter cited as Northwest Ordinance]. See generally H. Henderson, supra note 4 , at $371-76$.

92. See Ordinance for the Government of Western Territory, supra note 91, at 151-52.

93. See Northwest Ordinance, supra note 91, at 169.71 (providing inter alia for appointment of numerous officials and establishment of territorial legislature, and enunciating certain fundamental principles to be observed in territory).

94. Northwest Ordinance, supra note 91 , at 172 . 
Congress to follow in deciding any dispute between states, ${ }^{95}$ but these formal arrangements were fully employed only once. ${ }^{96}$ Congress usually would intervene in interstate disputes to resolve them without litigation. ${ }^{97}$ The paucity of formal proceedings thus hid a substantial amount of national activity in this area.

More visible was the post office, which developed in response to the government's communication needs and became an important centralizing institution. The leaders of the Revolution recognized early the importance of being able to communicate effectively with their sympathizers in other colonies, ${ }^{98}$ and the Continental Congress appointed its first postmaster nine months before the Declaration of Independence. ${ }^{99}$ Under authority granted by the Articles, ${ }^{100}$ Congress spurned the cheaper method of sending the mail by horse and rider and set up postal routes that would subsidize certain stagecoach services, in order to facilitate freer passage among the states. ${ }^{101}$ By the time of the drafting of the Constitution, national authority over the growing ${ }^{102}$ postal service was vigorously defended as increasing national cohesiveness. ${ }^{103}$

\section{B. The Machinery of Federalism: Administrative and Judicial Implementation of National Power}

During the 1770 s and 1780 s, a federal administrative structure began to emerge, a national court system started to function, and state courts began to take measures giving reality to the ideas of comity expressed in the Articles. The Articles Period thus saw the develop-

95. See Articles art. IX, 9 Journals at 916-18.

96. See Taylor, Trial at Trenton, 26 WM. \& MARY Q. 521 (3d ser. 1969). The dispute was between Pennsylvania and Connecticut and concerned title to the Wyoming Valley. After a proceeding with all the earmarks of a common law trial, the commissioncrs chosen to hear the case rendered judgment in favor of Pennsylvania, "and the government of Connecticut submitted as gracefully as possible." J. FiskE, supra note 8, at 152.

97. Seven such instances are discussed in Davis, Federal Courts Prior to the Adop. tion of the Constitution, 131 U.S. 1-lxiii app. (1889). See 1 J. Goeber, History of the Supreme Court of the United States: Antecedents and Begisinics to 1801, at 182-95 (1971); J. Welling, Land Politics of the $V^{\prime}$ nited States, in Addresses, Lectures and Other Papers, supra note 68, at 159.

98. See Vermilye, The Early New York Post Office, 13 Magazine AM. Hist. 113, 118-19 (1885).

99. See 2 Journals at 208-09.

100. Articles art. IX, 9 Journals at 919.

101. See Holmes, Shall Stagecoaches Carry the Mail?-A Debate of the Confederation Period, 20 WM. \& MARY Q. 555, 566, 573 (3d ser. 1963).

102. See M. JENSEN, NATION, supra note 4, at 363-64.

103. See The Froeralist No. 42 (J. Madison) 287 (J. Cooke ed. 1961); Rush, Address to the People of the United States (1787), reprinted in Principles AND Acts of THE Revolutiox in America 403 (H. Niles ed. Baltimore 1822). 
ment of a network of important links binding the country together and providing a permanent basis for national governance.

\section{The Embryonic Federal Administration}

To enforce its substantive powers, Congress in the 1780 s created the beginnings of a federal bureaucracy. Although this administrative framework was never more than rudimentary during the Articles Period, it was a significant element of the government of national federalism. The growth of a bureaucracy represented an expansive interpretation of national powers and a functional implementation of those powers on a small, but growing, scale.

With respect to the congressional powers over war, foreign affairs, and finance, a clear pattern emerged. In each case, Congress first established a standing committee of its own members to deal with the area, but ultimately delegated most of the burden to an outside administrative department created for the purpose. For example, Congress in June 1776 began to organize its exercise of war powers by creating a standing committee, the "Board of War and Ordnance." When the Board proved incapable of staying abreast of military affairs, ${ }^{104}$ a "Board of War" consisting of three persons not members of Congress was established in October 1777 and vested with important administrative duties and substantive powers. ${ }^{105}$ In 1781 , the legislators assigned many of this Board's duties to a single "Secretary at War." 106 During the remainder of the Articles Period, the incumbents of the post gradually expanded their authority and, in addition to auditing military accounts ${ }^{10 \overline{ }}$ and superintending military justice, took control over such matters as administering the lands granted as bounties to veterans and directing Indian affairs in the territories governed directly by Congress. ${ }^{10 s}$

Similarly, the legislative committee formed in $\mathbf{1 7 7 5}$ for the "purpose of corresponding with our friends in ... other parts of the

104. H. WARD, supra note 64 , at 2.3 (1962).

105. See 9 Journals at $818-20$. Among the many powers and dutics of the Board were to "stuperintend the raising, recruiting, and despatching, of the land forces" of the United States, to "lay before Congress proper and scasonable estimates" of the military supplies that would be needed, "and, in general, to superintend the several branches of the military department." Id. at 819 . The authorizing resolution contemplated that the Board members themselves would request legislation from Congress in order to obtain such greater powers as they might consider necessary. See id.

106. See 19 Journals at 126-27. This assignment took place three weeks before the Articles went into effect, and was based on the belicf that too much of the work of the Board's various incarnations was still reviewable by Congress, thus clogging the administrative machinery. See $\mathbf{H}$. W.1kD, supra note 64, at 5-6.

107. See H. WARD, supra note 64, at 83-88.

108. See M. JENSEN, Nation, supra note 4, at 365 . 
world"109 was replaced in 1781 by a regular "Department of Foreign Affairs" to conduct the country's diplomatic business. By 1782 the duties of the Secretary of Foreign Affairs were quite extensive and included communicating to the states complaints lodged against them by other states or citizens of other states. ${ }^{110}$

The administration of financial affairs displayed the same pattern. At first, Congress itself, through a committee, processed governmental disbursements; but even while this system lasted, it became necessary to hire a full-time staff to deal with the flow of business. Through detailed legislation enacted in 1779, Congress delegated many of its financial functions to a Treasury Board primarily composed of administrators who were not members of Congress. ${ }^{111}$ This significant step made the Treasury a more independent agency and opened the way for the creation of a class of professional officeholders on the policymaking level.112 The department underwent a number of structural changes during the 1780 s, each of which had the effect of increasing its functions, and by 1789 it had established a set of systematic accounting procedures ${ }^{113}$ that was to endure well into the next century.

\section{The Judicial System}

The Articles authorized Congress to establish a national appellate tribunal to decide maritime cases, a power the legislators themselves had exercised since 1775.114 Some maritime cases were heard on the national level over an eleven-year period, including about forty-nine that resulted in outright reversals of the state court. ${ }^{115}$ Execution of

109. 3 Jourials at 392. See also 5 Jouknals at 425 (formation of foreign alliances included in Lee's motion on independence).

110. See Guggenheimer, The Development of the Executive Detoartments, 1775-17s9, in Essays in the Constitutional History of the United States in tie Formative Period 162 (J. Jameson ed. 1889).

111. See 14 Journals at 903-08.

112. See H. HENDERSON, supra note 4, at 268.

113. See M. JeNSEN, NATION, supra note 4 , at $371-74$.

114. Congress resolved in Norcmber 1775 that it would begin hearing such cases, see 3 Journals at 374 , and the resolution was carried into effect the next year, sec H. Bourguignon, The First Federal Court 48-50 (1977). In March 1776, Congress also began to authorize and control privatecring. Sce 4 JoukNals at 230-32, 253-54. Under Articles art. IX, 9 Journals at 916, Congress was given the power of crecting "courts for the trial of piracies and felonies committed on the high seas." Congress exercised this prerogative on April 5, 1781, see 19 Journiss at 354-56, by designating certain state judges to sit on such cases.

115. See H. Bolirguigion, supra note 114, at 208, 217. Congressional transformation of the tribunal from a standing committec to a formal and independent court took place almost a year before ratification of the Articles authorized it. See Penhallow v: Doanc's Adm'rs, 3 U.S. (3 Dall.) 54 (1795) (holding that action had nerertheless been proper). See generally Davis, supra note 97, at xix-xlix (includes list of 104 decided admiralty cases). Certain of the court's opinions are printed at 2 U.S. (2 Dall.) 1-42. 


\section{Articles of Confederation}

the national judgment was, however, generally a routine matter. ${ }^{110}$

State courts in the Articles Period generally gave effect to the Articles' provisions for interstate comity. ${ }^{117}$ These provisions, argued before courts ${ }^{118}$ and construed and applied as authoritative by judges of the period, led to cases reaffirming national sovereignty ${ }^{119}$ and foreshadowing many aspects of later constitutional development. ${ }^{120}$

Much litigation focused on the full-faith-and-credit clause, as judgment creditors from one state frequently sought to bring suit on their judgments in the courts of other states. ${ }^{121}$ State judges regularly gave "full credence ... to judgments of the courts in any of the United States"122 so long as both parties had been within the jurisdiction of the court rendering judgment and had received or could have

116. Sec H. Botrguignox, supra note 114, at 236. There was substantial agreement that the area was a proper one for the application of a uniform national law. Indeed, most states explicitly instructed their admiralty judges "to use the resolves of Congress and the law of nations in preference to state laws as the legal norms for deciding cases of capture." Id. at 75. Congress expressly resolved, on December 4, 1781, that the "rules of decision in the several courts shall be the resolutions and ordinances of the United States in Congress asscmbled, public treatics when declared to be so by an act of Congress, and the law of nations, according to the general usages of Europe," 21 Jodr.sals at 1158 (basing action on ARTicles art. IX, 9 Journals at 915).

117. See p. 149 supra.

118. For example, in urging the Pennsylvania Supreme Court to enforce a Massachusetts attachment under the full-faith-and-credit clause of the Articles, counsel in one case argued that the Articles had created a union stronger than any known to history and that in adopting the clause "the authors of the system intended to make a Judgment in New-Jersey as binding in Pennsylvania, as if it had been obtained in any County of this State." Phelps r. Holker, 1 U.S. (1 Dall.) 261, 263 (Pa. 1788).

119. See, e.g., Respublica v. Sweers, 1 U.S. (1 Dall.) 41 (Pa. 1779). The defendant argued that he could not have defrauded the United States because, in 1777 and 1778, they were not a corporate entity "known in law." Id. at 44. His conviction was upheld, with the court writing: "From the moment of their association, the United States necessarily became a body corporate. . . ." Id.

120. For example, there are strong Eleventh Amendment undertones in the case of Nathan v. Virginia, 1 U.S. (1 Dall.) 77 note (Philadelphia C.P. 1781), in which the plaintiff was held unable to attach in Pennsylvania certain property belonging to the State of Virginia, in satisfaction of a debt.

Similarly, a dispute involving due process, judicial review, and privileges and immunitics arose in Bayard v. Singleton, 1 N.C. (Tay.) 5 (Super. Ct. 1787). In this ejectment action, the defendant claimed the benefit of a law providing that anyone who lived on a confiscated estate needed only to file proper proof of that fact in order to win automatically in any challenge to his title. The plaintiffs, represented by James Iredell and others, insisted that the law unconstitutionally deprived them of the right to trial by jury. The court upheld this position, saying, "these plaintiffs being citizens of one of the United States, or citizens of this State, by the confederation of all the States; which is to be taken as a part of the law of the land, unrepealable by any act of the General Assembly," could not be deprived by statute of the right to a jury trial. $I d$. at 7 .

121. Plaintiffs seemed undeterred by the fact that during the drafting of the Articles the Congress had defeated by a vote of 5.2 a proposal to add to the clause an explicit statement that "an action of debt may lic in a court of law of any State for the recovery of a debt duc on a judgment of any court in any other State." 9 Journals at 895; cf. note 148 infra (incorporation power presented similar situation under Con. stitution).

122. Kibbe v. Kibbe, I Kirby 119, 126 (Conn. Super. Ct. 1786). 
received a fair trial.123 Thus the full-faith-and-credit clause of the Articles allowed a debtor sued in Pennsylvania to defend successfully on the basis of his discharge under the insolvency laws of Maryland. ${ }^{124}$ Similarly, Massachusetts courts entertained suits on out-of-state judgments and, when appropriate, gave effect to out-of-state statutes. ${ }^{125}$

\section{Constitutional Federalism: Governmental Continuity, 1777-1789, and Its Implications}

The continuing growth of the authority of the national government in the Articles Period provides a useful context for examining the drafting and adoption of the Constitution. During the decade before 1787, the major principles of state deference to national power in certain areas and recognition of national citizenship were established, and major organs of the national government were created. Thus the theory and the practice of the period laid the foundation for the Constitution. ${ }^{126}$

\section{A. Textual Continuities}

Numerous provisions of the Constitution were both conceptual and textual descendants of provisions of the Articles or enactments during the Articles Period. For example, over half of the clauses in Article I, Section 8 of the Constitution, detailing the enumerated powers of Congress, can be traced back to specific provisions of the Articles. ${ }^{127}$

123. See id. (plaintiff's attempt to recover on a Massachusetts judgment fails because Massachusetts court was without personal jurisdiction over defendant); $c f$. Phelps v: Holker, I U.S. (1 Dall.) 261 (Pa. 1788) (where plaintiff's Massachusetts judgment was valid there only to extent of property actually seized, it would be given no greater effect in Pennsylvania).

124. Millar v. Hall, I U.S. (1 Dall.) 229 (Pa. 1788); accord, Thompson v. Young, 1 U.S. (I Dall.) 294 (Philadelphia C.P. 1788). It secms clear that these cases orcrruled James v. Allen, 1 U.S. (1 Dall.) 188 (Philadelphia C.P. 1786), which reached an opposite result.

125. See Nelson, supra note 54, at 21.

126. See R. Brown, Reinterpretation of the Formation of the AMerican ConstituTron 1-2 (1963) ("The Constitution did not spring full-blown from the pens of the Founding Fathers as something completely new in government ... [IW]c must consider it as the product of a long evolutionary development.")

127. These powers include those relating to: borrowing (rompare U.S. CoNsT. art. I, $\$ 8$, cl. 2 with ARTICles art. IX, 9 Jolrnals at 920); Indian affairs (compare U.S. CoNst. art. I, $\$ 8$, cl. 3 with ARTICles art. IX, 9 Journals at 919); commercial regulation (compare U.S. Const. art. I, $\$ 8$, cl. 5 (power " $[$ t]o coin Money, regulate the Value thereof, ... and fix the Standard of Weights and Measures") wilh ArTicr.es art. IX, 9 Jourvals at 919 ("power of regulating the alloy and value of coin struck by their own atuthority, or by that of the respective states; fixing the standard of weights and measures")); the post office (compare U.S. Const. art. I, $\$ 8$, cl. 7 wilh ArTicl.es art. IX, 9 Joursils at 919); creation of inferior courts (compare U.S. CoNsT. art. I, $\$ 8$, cl. 9 with ArTicl.s art. IX, 9 JockNiss at 916); international law offenses (compare U.S. Cosst. art. I, $\$ 8, \mathrm{cl} .10$ 
Similarly, the congressional power "[ $t] 0$ make Rules for the Government and Regulation of the land and naval Forces"128 was added to the Constitution "from the existing Articles of Confederation," 129 and the authority "to borrow money or emit bills on the credit of the United States" 130 was embodied in the right "[ $t] 0$ borrow Money on the credit of the United States." 131

Madison cited the Articles provision giving Congress the power to defray from the common treasury all "expences, that shall be incurred for the common defence or general welfare"132 when he argued in support of the general welfare clause of the Constitution empowering Congress "to pay the Debts and provide for the common Defence and general Welfare of the United States."133

Both the Articles and the Constitution barred the states from interfering with the exercise of the enumerated national powers. Many of the restraints on state action in the fields of war and foreign affairs found in the Constitution, such as those on authorizing privateering or entering into foreign alliances, had close textual ties to the corresponding provisions of the Articles. ${ }^{134}$ Similarly, safeguards for national deliberations from outside interference found their inspiration in the Articles. ${ }^{135}$ The restraints on national power in the

(power " [t]o define and punish Piracies and Felonies committed on the high Seas, and Offenses against the Law of Nations") with Articles art. IX, 9 Journals at 916 ("appointing courts for the trial of piracies and felonics committed on the high seas")); and sereral aspects of military affairs (compare U.S. CoNsT. art. I, $\$ 8$, cls. 11, 13, 14, 16 (powers to declare war, maintain navy and regulate armed forces) with ARTICLES art. IX, 9 Jolrnals at 915-20 (granting Congress same powcrs)).

Although this list of textual similarities could be appreciably extended by considering other sections of the Constitution, the powers conferred in the Articles were often not as extensive as those conferred in the corresponding clauses of the Constitution. Moreover, numerous provisions of the Constitution-including the very significant ones creating the Presidency and granting a national laxing power-lhad no counterparts in the Articles.

128. U.S. CoNst. art. I, \$ 8, cl. 14.

129. 2 M. Farrand, The Records of the Federal Convention of 1787, at 330 (1911); see Articles art. IX, 9 Journals at 919.

130. Articles art. IX, 9 Journals at 920.

131. U.S. Consr. art. I, $\$ 8$, cl. 2.

132. Articles att. VIII, 9 Journals at 913; sce ThE Feder.ilist No. 41 (J. Madison) 278 (J. Cooke ed. 1961). During the Articles Period Congress recommended to the states an amendment to the Articles relating to the apportionment of charges incurred for the general welfare. The proposed language was closely followed in the corresponding provision of the Constitution. Compare 24 Jours.ls at 260-61 with U.S. Const. art. I, $\$ 2, \mathrm{cl} .3$.

133. U.S. Const. art. I, $\$ 8$, cl. 1.

134. Compare U.S. CoNst. art. I, \$ 10, cls. 1, 3 with AkTicles art. VI, 9 Journals at" 911-12.

135. The Articles provided:

Frecdom of specch and debate in Congress slaall not be impeached or questioned in any court or place out of Congress: and the members of Congress shall be protected in their persons from arrests and imprisonments, during the time of 
two documents are also closely parallel. ${ }^{136}$

The clauses dealing with national citizenship are yet another example of heavy borrowing by the framers of the Constitution from the Articles Period. The full-faith-and-credit clause was taken over virtually intact, ${ }^{137}$ as was the operative language of both the privileges-and-immunities clause and the extradition clause. ${ }^{138}$

The Constitution's protections of individual rights also reflected political developments under the Articles. The Constitution clearly showed, for instance, the strong influence of the Northwest Ordinance, which had provided for freedom of religion, the availability of habeas corpus and trial by jury, the prohibition of "cruel or unusual punishments," requirements of due process of law before deprivation of liberty or property, and the security of private contracts against later legislation. ${ }^{339}$

\section{B. Continuities in Interpretation and Application}

The Articles Period also bequeathed to the framers of the Consituation the practice of expansive interpretation of governing legal

their going to and from, and attendance on Congress, except for treason, felony, or breach of the peace.

Articles art. V, 9 Journals at 910.

The Constitution states:

[The Senators and Representatives shall] in all Cases, except Treason, Felony and Breach of the Peace, be privileged from Arrest during their Attendance at the Session of their respective Houses, and in going to and returning from the same; and for any Speech or Debate in either House, they shall not be questioned in any other Place.

U.S. Const. art. I, $\$ 6$, cl. 1.

136. Compare U.S. Const. art. I, $\$ 6$, cl. 2 with ARticles art. V, 9 Journals at 910 (plural office-holding); compare U.S. CoNst. art. I, $\$ 9$, cl. 7 with ARTICLEs art. IX, 9 Journals at 920 (accounting for public funds); compare U.S. CoNsT. art. I, $\$ 9$, cl. 8 with ARTICles art. VI, 9 Journals at 911 (prohibition on conferring titles of nobility).

137. Compare U.S. Const. art. IV, $\$ 1$ ("Full Faith and Credit shall be given in each State to the public Acts, Records, and judlicial Procecdings of every other State.") with Articles art. IV, 9 Journals at 909 ("Full faith and credit shall be given in each of these states to the records, acts, and judicial procecdings of the courts and magistrates of every other State.")

138. Compare U.S. Const. art. IV', $\$ 2$, cl. I "The Citizens of cach State shall be entitled to all Privileges and Immunitics of Citizens in the several States.") with ARTICLES art. IV, 9 Journats at 908 ("[T]he free inhabitants of each of these states . . . shall be entitled to all privileges and immunities of free citizens in the sereral States . . . ."); compare U.S. CoNST. art. IV, $\$ 2$, cl. 2 (any person cliarged with crime. "who shall flee from Justice, and be found in another Stitc, shall on demand of the executive Authority of the State from which he fled, be delivered up, to be removed to the State having Jurisdiction of the Crime") with AkTiciss art. IV. 9 JoukN.ls at 909 (if anyone charged with crime shall "flee from justice and be found in any of the United States, he shall, upon demand of the governor or exccutive power of the state from which he fled, be delivered up and removed to the Statc having jurisdiction of his offence").

139. See Northwest Ordinance, stupra note 91, at 172-74. The Ordinance also banncd "slavery [or] involuntary servitude . . . otherwise than in punishment of crimes whereof the party shall have been duly convicted." $I d$. 
instruments. With or without formal legal authority, the national government had repeatedly taken a broad view of its own powers, and the states and the people had acquiesced. The Continental Congresses assumed many economic powers, ${ }^{140}$ exercising numerous functions of sovereignty well before the Declaration of Independence, ${ }^{141}$ and contemporaries generally had very little patience with the concept that the Articles were intended to be rigid limitations on the developing powers of the national government. ${ }^{142}$

The broad assertions of collective sovereignty advanced in external affairs, and the generous reading of congressional power used to justify the imposition of a national trade embargo and the creation of a detailed administrative machinery for the western territories, reflect this attitude. ${ }^{143}$ The expansive interpretation of the Articles put forward in support of congressional incorporation of the Bank of North America $^{144}$ is another example. In defending the institution against a threatened revocation of its charter in Pennsylvania, ${ }^{145}$ James Wilson argued that, despite the Articles' reservation to the states of all nondelegated powers, ${ }^{146}$ the plan of union required that "[w]henever an object occurs, to the direction of which no particular state is competent, the management of it must, of necessity, belong to the United States."147 Even if Wilson's views were not shared by all those who voted for the national bank legislation, his arguments do suggest the

140. See Jensen, TESTAMENTS, supra note 2, at 61.62.

141. See Penhallow v. Doane's Adm'rs, 3 U.S. (3 Dall.) 54, 80-82, 109-13 (1795) (summarizing activitics of Congress during war); $R$. NichoLs, THE INvENTION OF THE AMERICAN Political Parties 120-24 (1967) (opening of American ports to foreign trade, authorizing death by court martial for spies and traitors, adopting rules for nary and capture of prizes, creating committec to seek foreign aid); Jensen, TestameNTs, supra. note 2, at 61-62 (creation of army and appointment of generals, issuance of paper money).

142. See The Federalist No. 44 (J. Madison) 303 (J. Cooke ed. 1961) ("It would be easy to shew if it were necessary, that no important power, delegated by the articles of confederation, has been or can be executed by Congress, without recurring more or less to the doctrine of construction or implication."); J. WiLson, supra note 84, at 829-30. One reason for this attitude was doubtless the realization that the Articles themselves represented essentially a codification of existing congressional practices. See J. FiskE, supra note 8, at 101; DocumeNtaky History, supra note 2, at 403.

143. See pp. 152-55 supra.

144. For the proceedings of Congress on the incorporation of the Bank, see 20 Jotrdals at 545-48. For Robert Morris's observations on the plan, see 4 CoRrespoNDENCE, supra note 66, at 566-68. This was not the first congressional foray into the banking field; in 1780, Congress had pledged the faith of the United States to protect from loss subscribers to the Bank of Pennsylvania. See B. Hammond, Banks and Politics in AMERICA 43 (1957).

145. See R. Brunhouse, The Counter-Revolution in Pennsylvinia 173-75 (1942); B. H.MMOND, supra note 144 , at 52-63.

146. See Articles art. II, 9 Journils at 908 ("Each state retains its sorereignty, freedom and independence, and every power, jurisdiction, and right, which is not by this confederation expressly delegated to the United States . . . .")

147. J. WiLson, supra note 84 , at 829 . 
flexible way in which the Articles often were interpreted to allow the establishment of pragmatic national institutions. ${ }^{148}$

The result of this process was that the overall structure of the government chartered by the Constitution was similar in many respects to the one that already existed under the Articles. A national legislature already engaged actively in the creation of national laws, treaties and policies; a national court of appeals, the institutional predecessor of the Supreme Court, ${ }^{149}$ rendered judgments superior within its jurisdiction to state court decisions; and federal administrative departments carried the national will into execution. ${ }^{150}$ Both the old and the new national governments could deal directly with individuals in certain instances, ${ }^{151}$ and both systems bound individuals into a common political community by full-faith-and-credit and privilegesand-immunities clauses. ${ }^{152}$ As the Constitution government began its

148. In the case of the western lands, the framers of the Constitution found it neces. sary to write in a provision granting to Congress the power it had already been exexcising: "The Congress shall have Power to dispose of and make all needful Rules and Regulations respecting the Territory or other Yroperty belonging to the United States ... U.S. CoNst. art. IV, $\$ 3, \mathrm{cl}$. 2. The convention defeated a motion to grant similar explicit sanction to the power that Congress had exercised in the case of the Bank of North America, voting down a proposal that the United States be allowed "to grant charters of incorporation where the interest of the U.S. might require \& the legislative provisions of individual States may be incompetent." See 2 M. FARRAND, supra note 129, at 615-16. As a result, the debate over the legitimacy of implying such a power continued into the next century. See, e.g., McCulloch v. Maryland, 17 U.S. (4 Wheat.) 316 (1819); 3 M. FARRAND, supra note 129, at 362-64, 375-76.

149. See Act of May 8, 1792, ch. 36, $\$ 12,1$ Stat. 275 (1792); Jameson, The Predecessor of the Supreme Coutt, in Essays in the Constitutional History of the United States, supra note 110, at 44 . On more than one occasion, Chief Justice Marshall brusquely rejected the argument that the Supreme Court could not carry into effect decrees of the prize court. See, e.g., Jennings v. Carson, 8 U.S. (4 Cranch) 2, 4-8, 21, 25 (1807).

150. See Guggenheimer, supra note 110 , at $183-84$. But see L. White, The Federalists: A Study in Administrative History 1 (1948) (Washington administration inherited almost no functioning administrative apparatus from Confederation).

151. As James Madison put it:

In cases of capture, of piracy, of the post-office, of coins, weights and measures, of trade with the Indians, of claims under grants of land by different States, and above all, in the case of trials by Courts-martial in the army and navy, by which death may be inflicted without the intervention of a jury, or even of a civil Magistrate; in all these cases the powers of the confederation operate immediately on the persons and interests of individual citizens.

The Federalist No. 40 (J. Madison) 262 (J. Cooke ed. 1961). But cf. National League of Cities v. Usery, 426 U.S. 833, 844 (1976) (citing Lane County v. Oregon, 74 U.S. (7 Wall.) 71 (1869)) (Constitution substituted government acting directly on individuals for one that did not do so).

152. It is, however, true that the Constitution government, like the Articles government, was in some respects far removed from the daily life of the citizen. See J. Younc, THE Washington CoMmunity 1800-1828, at 28-34 (1966). See also McColley, Jefferson's Rivals: The Shifting Character of the Federalists, Midcontıne.t A A. Stud. J., Spring, 1968, at 24 ("Under the supposedly more perfect gorcrnment of the Constitution of 1787 we 
work, the Department of War remained intact under the same individual, ${ }^{153}$ and the Post Office employees continued to follow the same routines as before the transition. ${ }^{15}$

\section{Conclusion}

The events and experiences of the period from 1777 to 1787 yielded broad support for a national government operating under a "federal Constitution adequate to the exigencies of Government and the preservation of the Union." 155 Both the Articles and the Constitution represented a series of pragmatic compromises that codified and expanded on existing practices and impliedly sanctioned flexible interpretation in their implementation. The common law attorneys who drafted and later construed both charters eschewed strict literalism and political inflexibility, as they sought a solution to the overriding problem of creating a national union.

\section{Appendix}

The significant textual changes made in the Articles during the drafting process are summarized in the following table. One or two alterations that appeared to be merely verbal were not included. Although in several cases the precise strengthening or weakening effect of a change is questionable, the significance of the table lies not in the individual items, but rather in the fact that no clear pattern of changes in either direction is discernible.

had whiskey rebellions, western conspiracies, financial confusion and secessionist plots quite as alarming as the troubles of the 1780 's.")

Indeed, it had been argued in favor of the adoption of the Constitution that it in fact conferred few new powers on the federal government. See The Federalist No. 38 (J. Madison) 247 (J. Cooke ed. 1961); Nelson, supra note 54, at 19 n.70. As Madison put it:

The present Congress can make requisitions to any amount they please; and the States are constitutionally bound to furnish them; they can emit bills of credit as long as they will pay for the paper; they can borrow both abroad and at home, as long as a shilling will be lent. Is an indefinite power to raise troops dangerous? The Confederation gives to Congress that power also; and they have already begun to make use of it. . . . The existing Congress, without any . . . controul, can make treaties which they themselves have declared, and most of the States have recognized, to be the supreme law of the land.

THE FEDERALIST, supra, at 247.

153. See M. Jensen, Nation, supra note 4, at 365; H. WARD, supra note 64, at 101.03.

154. See Guggenheimer, supra note 110 , at $182-83$.

155. 32 Journals at 74 (call for Convention); see E. Ferguson, The Power of the Purse 337 (1961) ("That the crisis of the Union inspired the calling of the Federal Convention indicates such a level of agrecment as to suggest that there was no crisis at all ....") 
Summary of Changes in Articles of Confederation

Article
Number
IN Final in Final
DRAFT

2

3

4

5

6

8

9

10

11

12

13
SUbJECT

Reserved powers

Reserved powers

Nature of union

Interstate comity

Interstate comity

Delegate's appointment

Congressional immunity

Number of delegates

Officeholding restriction

Marque and reprisal

Taxation

Maritime jurisdiction

Congressional judicial power

Treaties of commerce

Appointment of judges

Private land disputes

Regulation of money

Indian affairs

Indian affairs

Western lands

Post office

Commissioning of officers

Adjournment of Congress

Military powers of Congress

Council President's tenure

Expenditures

Expenditures

Accounting for expenditures

Naval forces

Expenses of land forces

Taxation

Peace treaties

Peace treaties

Appropriation

Commander-in-chief appointment

Council of State

Military powers of Council

Powers of Council

Admission of Canada

Honoring of old debts

Submission to national power
Chavged

BETWEEN EFFECT ON

Draft Central

NUMBERS GOVERNMENT

1-2 Strengthens

2-3 Weakens

[1-3 weakens]

1-2 Weakens

1-2 Weakens

2-3 Strengthens greatly

[1-3 strengthens]

1-2 Strengthens

2-3 Strengthens

2-3 Strengthens

2-3 Weakens

2-3 Weakens slightly

2-3 No effect

1-2 Weakens

2-3 Weakens

2-3 Weakens

2-3 Weakens

2-3 Strengthens

2-3 Weakens

1-2 Weakens

2-3 Weakens

1-2 Weakens

1-2 Strengthens

2-3 Strengthens

1-2 Strengthens

1-2 Strengthens

2-3 Weakens

1-2 Strengthens

2-3 Strengthens

2-3 Weakens

1-2 Strengthens

2-3 Strengthens

1-2 Strengthens

1-2 Strengthens

2-3 Weakens

1-2 [ $1-3$ no effect]

1-2 Wcakens

2-3 Strengthens

1-2 Weakens

2-3 Strengthens

2-3 Strengthens

2-3 Strengthens

1-2 Strengthens

Totals

Changes between Drafts 1 and 2: 18

Changes between Drafts 1 and 2 strengthening/weakening the central government: 10/18 Changes between Drafts 2 and 3: 23

Changes between Drafts 2 and 3 strengthening/wcakening the central gorernment: 11/11 Changes between Drafts 2 and 3 not affecting the central government: $I$ 